\title{
Alicja Kicowska
}

Niepaństwowa Wyższa Szkoła Pedagogiczna

w Białymstoku

\section{Problematyka szkolnictwa rolniczego na lamach prasy olsztyńskiej (1945-1956)}

Wraz $\mathrm{z}$ rozwojem cywilizacyjnym wzrastała $\mathrm{w}$ różnych sferach życia, w tym również w edukacji, rola mediów. Dlatego też takie media jak książka i prasa (gazety i czasopisma) są we współczesnych badaniach historyczno-edukacyjnych cennym, aczkolwiek nie w pełni wykorzystanym źródłem ${ }^{1}$, mimo że za uznaniem prasy jako źródła opowiada się obecnie wielu historyków ${ }^{2}$.

Od XIX w. prasa przeszła „długą drogę ku swej mozaikowej formie. [...] Mozaika to rodzaj zbiorowego lub zespołowego wizerunku i coś, co wymusza głębokie zaangażowanie odbiorcy. Owo zaangażowanie ma raczej charakter społeczny niż osobisty, bardziej włączający niż wyłączający ${ }^{3}$. Prasa jest więc - według klasyfikacji J. Topolskiego - źródłem pośrednim-adresowanym, zawierającym interpretację świata dokonaną przez autora lub autorów źródła. Dlatego też ,historyk chcąc wydobyć z takich źródeł informacje, musi przeprowadzić swoją interpretację, tzn. dokonać interpretacji interpretacji już zawartej w źródle"4. Ramy niniejszego opracowania ograniczają możliwość przedstawienia wymagań metodologicznych tej interpretacji oraz trudności, jakie się z tym wiążą ${ }^{5}$.

${ }^{1}$ Por. m.in. T. Jałmużna, Twórczość literacka źródtem do historii wychowania; D. Koźmian, Czasopisma uczniowskie jako cenne źródło do badań dziejów wychowania i szkolnictwa w Drugiej Rzeczypospolitej; I. Michalska, Możliwości wykorzystania czasopisma dla dzieci jako źródta wiedzy o wychowaniu, [w:] Konteksty i metody w badaniach historyczno-pedagogicznych, red. T. Jałmużna, I. Michalska, G. Michalski, Kraków 2004.

${ }^{2}$ Zagadnienie to omawianie było ostatnio na XVIII Powszechnym Zjeździe Historyków, który odbył się 16-19 września 2009 r. w Olsztynie.

${ }^{3}$ M. McLuhan, Zrozumieć media. Przedłużenia człowieka, Warszawa 2004, s. 273, 279.

${ }^{4} \mathrm{~J}$. Topolski, Jak się pisze i rozumie historię. Tajemnice narracji historycznej, Warszawa 1996, s. 341.

${ }^{5}$ Szerzej na ten temat w: A. Kicowska, Prasa jako źródło $w$ badaniach historyczno-edukacyjnych, [w:] Konteksty i metody..., s. 197-199. 
Z uwagi na fakt, że prasa jest środkiem komunikacji społecznej, dzięki której kształtuje się świadomość społeczną ${ }^{6}$, zasadne jest pytanie: czy i jaką problematykę dotyczącą szkolnictwa rolniczego podejmowała prasa olsztyńska i jaki wizerunek tej szkoły kształtowała w latach 1945-1989? W niniejszym opracowaniu przedstawione będą jedynie dwa pierwsze okresy ${ }^{7}$ wyróżniane w periodyzacji dziejów prasy w Polsce Ludowej w skali ogólnokrajowej i regionalnej, jak również charakterystyczne dla powstania i przemian szkolnictwa rolniczego:

1. Pierwszy okres, obejmujący lata 1944-1948, to czas powstania i krystalizowania się nowej prasy opartej na zasadzie społecznego charakteru jej własności. W konsekwencji powstająca prasa „została skupiona w rękach partii i stronnictw politycznych, organizacji społecznych oraz instytucji państwowych"». W szkolnictwie rolniczym w latach 1944-1948 następowała stopniowa odbudowa, a na Warmii i Mazurach organizacja, od podstaw, szkolnictwa według wzorów przedwojennych.

2. Drugi okres, obejmujący lata 1949-1956, to czas realizacji modelu prasy radzieckiej, której podstawy tak określili kolejni przywódcy partyjni: gazeta „to nie tylko zbiorowy propagandysta i zbiorowy agitator; to również organizator zbiorowości” (Lenin); gazeta jest „najpotężniejszą bronią naszej Partii” (Stalin), a Chruszczow gazetę określił mianem „naszej głównej broni ideologicznej”. Głównym celem przemian szkolnictwa rolniczego w latach 1949-1956 było dostosowanie go do potrzeb programu kolektywizacji wsi. Likwidacji zatem uległy formy kształcenia zorganizowane na potrzeby gospodarki indywidualnej. Rozwój szkolnictwa rolniczego dokonał się więc jedynie w zakresie kształcenia na poziomie średnim. Po 1952 r. główny trzon szkolnego kształcenia rolniczego stanowiły intensywnie rozbudowywane technika.

Natomiast w powojennych dziejach prasy olsztyńskiej wyróżnia się w interesującym nas okresie (1945-1956) dwa podokresy:

a) okres powstania prasy oraz organizacji podstawowej bazy jej działania przypadający na lata $1945-1947$;

b) okres realizacji radzieckiego modelu prasy przypadający na lata 19511956, bowiem w latach 1947-1951 w Olsztyńskiem nie było prasy miejscowej, a ukazywały się jedynie mutacje prasy centralnej ${ }^{10}$.

Po II wojnie światowej prasa spełniała istotną rolę w tworzeniu nowego życia na Warmii i Mazurach. Wśród pierwszych tytułów prasowych, jakie ukazy-

\footnotetext{
${ }^{6}$ Por. T. Goban-Klas, Media i komunikowanie masowe. Teorie $i$ analizy prasy, radia, telewizji i Internetu, Warszawa-Kraków 1999.

${ }^{7}$ Badania dotyczące lat późniejszych (1957-1989) nie zostały jeszcze zakończone.

${ }^{8}$ B. Łukaszewicz, Prasa informacyjno-polityczna Warmii i Mazur 1945-1975, Warszawa 1982, s. 29.

${ }^{9}$ Podano za: M. McLuhan, Zrozumieć media..., s. 281.

${ }^{10}$ B. Łukaszewicz, Prasa informacyjno-polityczna ..., s. 151-152.
} 
wały się w Olsztynie ${ }^{11}$ i podjęły problematykę szkolnictwa rolniczego, należy wymienić „Wiadomości Mazurskie”, które powstały z inicjatywy Wojewódzkiego Urzędu Informacji i Propagandy w Olsztynie. Cele pisma zakładały informowanie i integrację społeczeństwa olsztyńskiego, lecz „w rzeczywistości popołudniówka była narzędziem propagandowym obozu władzy i wyznaczono jej istotną rolę w oddziaływaniu na społeczeństwo w duchu programu głoszonego przez Polską Partię Robotniczą""12.

Na łamach ,Wiadomości Mazurskich” (w czasie edycji od 1 sierpnia 1945 r. do 30 kwietnia 1947 r.) ukazały się pierwsze cztery publikacje prasowe dotyczące organizacji szkolnictwa rolniczego w regionie. Oprócz informacji o powstaniu na szczeblu wojewódzkim i powiatowym władz oświaty rolniczej oraz planach dalszego rozwoju szkolnictwa rolniczego w województwie olsztyńskim ${ }^{13}$ „Wiadomości Mazurskie” w trzech pozostałych artykułach podejmowały problematykę średniego szkolnictwa rolniczego ${ }^{14}$. Eksponowanie problematyki średniego szkolnictwa rolniczego przygotowującego kadry do dużych gospodarstw rolnych (państwowych i spółdzielczych), a pomijanie tematyki niższego szkolnictwa rolniczego przygotowującego do pracy w gospodarstwach indywidualnych może wskazywać na propagandowy dobór tematyki (w związku z, planowaną już wówczas przez niektórych działaczy PPR, kolektywizacją rolnictwa ${ }^{15}$ ). Było to bowiem - jak stwierdza B. Łukaszewicz na podstawie analizy zawartości „Wiadomości Mazurskich” - „pismo regionalne ze znaczną zawartością materiałów agitacyjno-propagandowych spełniających funkcję społeczno-politycznego oddziaływania na odbiorcę"

W latach 1948-1951 w Olsztyńskiem nie było prasy miejscowej, lecz ukazywały się mutacje tytułów centralnych.

Kontynuacją zlikwidowanych z końcem kwietnia 1947 r. „,Wiadomości Mazurskich” była mutacja „Życia Warszawy” nosząca nazwę „Życie Olsztyńskie""17. W 1948 roku (od 1 lutego do 15 grudnia) ukazywała się także mutacja

${ }^{11}$ Już w kwietniu 1945 r. wydawana była w Olsztynie w dwóch egzemplarzach gazetka ścienna wywieszana w Ratuszu i stołówce Urzędu Pełnomocnika Rządu na Okręg Mazurski. Zamieszczano w niej najważniejsze wydarzenia polityczne i rozporządzenia Urzędu Pełnomocnika. Od maja do grudnia 1945 r. ukazywał się „Głos Ziemi”, organ Stronnictwa Ludowego na Okręg Mazurski. Był to tygodnik społeczno-polityczny adresowany do wykształconego i zaangażowanego w sprawy regionu odbiorcy miejskiego.

${ }^{12}$ B. Lukaszewicz, Prasa Olsztyna drugiej polowy XX stulecia, [w:] Olsztyn 1945-2005. Kultura i nauka, red. S. Achremczyk, W. Ogrodziński, Olsztyn 2006, s. 549.

${ }^{13}$ Oświata rolnicza w województwie mazurskim, „Wiadomości Mazurskie” 1946, nr 119.

${ }^{14}$ W Szczytnie powstaje Gimnazjum Gospodarki Wiejskiej, „Wiadomości Mazurskie” 1946, nr 31; (a.d.), Dopomóżmy młodzieży średnich szkół rolniczych, „Wiadomości Mazurskie” 1946, nr 300; Szkolnictwo w Moragu rozwija się pomyślnie, „Wiadomości Mazurskie” 1947, nr 60.

${ }^{15}$ Por. A. Kicowska, Szkola rolnicza w Polsce w latach 1944-1989, Olsztyn 1998.

${ }^{16}$ B. Łukaszewicz, Prasa informacyjno-polityczna ..., s. 93.

17 „Życie Olsztyńskie” ukazywało się do 1.06 .1960 r. 
„Głosu Ludu” dziennika PPR - „Olsztyński Głos Ludu”, w którym zamieszczono w czerwcu 1948 r. dwa artykuły poruszające sprawy rekrutacji kandydatów do szkół rolniczych i warunków nauki. Podkreślano też, że specjalne znaczenie przywiązuje się do „werbunku uczniów pochodzenia autochtonicznego, którzy przede wszystkim typowani będą na stypendystów" ${ }^{\prime 18}$.

Dopiero w 1951 r. powołano w Olsztynie dziennik Komitetu Wojewódzkiego Polskiej Zjednoczonej Partii Robotniczej - „Głos Olsztyński”, który był typowym regionalnym dziennikiem informacyjno-politycznym. Pierwszy numer tej gazety ukazał się 1 września i w nim redakcja tak przedstawiała zadania gazety: „oddajemy pierwszy numer pisma mas pracujących miast i wsi ziemi olsztyńskiej. Zadaniem naszego pisma jest nie tylko informować, ale uczyć i wychowywać, pomagać w pracy i walce $\mathrm{z}$ wrogiem klasowym, mobilizować do coraz nowych i śmielszych zadań stojących przed klasą robotniczą i całym narodem polskim w jego walce o pokój i Plan Sześcioletni"19. Jednorazowy nakład „Głosu Olsztyńskiego” wynosił około 33000 egzemplarzy w 1951 r. i około 43000 egzemplarzy w 1956 r. co oznacza, że gazeta ta była bardziej dostępna niż 8-tysięczny nakład „Życia Olsztyńskiego".

Spośród przedstawionej wyżej prasy ukazującej się na Warmii i Mazurach w latach 1945-1956 kwestie szkolnictwa rolniczego najczęściej przedstawiane były na łamach „Życia Olsztyńskiego” (53 razy od czerwca 1947 do września 1955) i „Głosu Olsztyńskiego” (37 razy od września 1951 do listopada 1956). Ogółem przez 10 lat na łamach prasy adresowanej do olsztyńskiego odbiorcy 90 razy poruszono problem edukacji rolniczej. To statystyczne zestawienie wskazuje, że problematyka szkolnictwa rolniczego nie była szczególnie ,atrakcyjnym" tematem prasowym, mimo że szkoła ta włączona została w zadania kolektywizacji wsi, a porównanie $\mathrm{z}$ akcją propagandową jaką podjęła prasa olsztyńska na temat kolektywizacji wsi dobitnie tego dowodzi (jedynie na łamach „Głosu Olsztyńskiego” w latach 1951-1953 ukazało się ponad tysiąc publikacji na temat kolektywizacji $\mathrm{wsi}^{20}$ ). Największe natężenie publikacji na temat szkolnictwa rolniczego zaznaczyło się w latach 1951-1954, w których 44 artykuły traktowały o różnych sprawach tego szkolnictwa.

Najliczniejszą grupę - 76 spośród 96 artykułów prasowych zamieszczonych w latach 1945-1956 - stanowiły publikacje, których treść zawierała informację, propagandę, ocenę; do 1947 r. więcej w nich było informacji, a po $1947 \mathrm{r}$. eksponowana była funkcja opiniotwórcza i propagandowa tych wypowiedzi. Autorzy publikacji informowali o naradach różnych gremiów w sprawach

${ }^{18}$ (zet), Szkoły zawodowe czekaja na młodzież, „Olsztyński Głos Ludu” 1948, nr 173; (rk), Nowe szkoły rolnicze w województwie olsztyńskim, „Olsztyński Głos Ludu” 1948, nr 177.

${ }^{19}$ Do czytelników, „Głos Olsztyński” 1951, nr 1.

${ }^{20}$ M. Walerych, Kolektywizacja wsi olsztyńskiej na łamach „, Głosu Olsztyńskiego” w latach 1951-1953, Olsztyn 1996 (mpis pracy magisterskiej, WSP w Olsztynie). 
oświaty rolniczej, wskazywali na potrzeby kształcenia rolniczego na Warmii i Mazurach, informowali o różnych formach i trybach kształcenia, podawali lokalizację i profil programowy danej szkoły, wskazując przy tym zwykle na dobre warunki nauki, zakwaterowania w internacie, pomoc stypendialna. Szkoły i nauka $\mathrm{w}$ nich przedstawiane były na ogół w pozytywnym, zachęcającym świetle $^{21}$. Najcenniejsze w sensie informacyjnym dla ówczesnego czytelnika, a źródłowo dla badacza najnowszych dziejów edukacji na Warmii i Mazurach są te wypowiedzi prasowe, które zgodnie z rzeczywistością przedstawiały stan szkolnictwa, plany przekształceń i rozwoju, informacje o poszczególnych szkołach, warunki przyjęcia i nauki, oferowaną pomoc socjalno-bytową itp.

Zmiana preferowanych funkcji prasy $\mathrm{z}$ informacyjnych na opiniotwórcze i propagandowe znalazła swoje odzwierciedlenie także w prasowych wypowiedziach na temat szkolnictwa rolniczego. Na przykład w artykule propagującym szkoły praktyków specjalistów wiejskich ${ }^{22}$ pisano, że są to szkoły awansu społecznego dla młodzieży wiejskiej, w których odbywa się nie tylko proces kształcenia, ale też wychowania w duchu postępowej ideologii, a przeważająca większość uczniów to aktywiści Związku Młodzieży Polskiej współpracujący ze środowiskiem wiejskim, zapowiadano - powołując się na słowa ministra rolnictwa - że „rozwój tych szkół postępować będzie w tempie siedmiomilo-

${ }^{21}$ M.in.: Odremontowane gimnazjum rolnicze w Szczytnie czeka na uczniów, „Życie Olsztyńskie" [dalej: ŻO] 1947, nr 137; Każda gmina ma swojq szkotę, ŻO 1947, nr 143; Sprawy oświaty rolniczej $w$ województwie olsztyńskim na plenum OWRN, ŻO 1948, nr 100; Jaka szkołe chce skończyć? Szczegółowo informujemy młodzież o szkołach zawodowych w województwie olsztyńskim, ŻO 1948, nr 165; Nowe szkoły rolnicze w województwie olsztyńskim, „Olsztyński Głos Ludu" 1948, nr 177; Szkolnictwo rolnicze na ziemi warmińsko-mazurskiej rozwija się pomyślnie, ŻO 1948, nr 176; W szkole rolniczej w Ploskini brak uczniów, ŻO 1948, nr 292; 9 nowych szkót zawodowych dostarczy fachowców-praktyków naszemu rolnictwu, ŻO 1950, $\mathrm{nr}$ 13; Rok wielkiego przełomu w szkolnictwie, ŻO 1950, nr 228; Do pracy w spóldzielniach produkcyjnych przygotowuje się młodzież liceów rolniczych, ŻO 1950, nr 120; Nowe kadry specjalistów handlu rolnego ksztatci szkoła $w$ Kętrzynie”, ŻO 1950, nr 202; Przyszli agronomowie na praktyce $w$ spótdzielniach produkcyjnych, „Głos Olsztyński” [dalej: GO] 1951, nr 24; Szkoły dla pracujacych przyjmuja nadal zapisy, ŻO 1951, nr 273; Dodatkowe zapisy do Szkoły Księgowych Spółdzielni Produkcyjnych i Szkoty Sanitarno-Weterynaryjnej, GO 1953, nr 27; Zapisy do podstawowych szkót rolniczych, ŻO 1953, nr 309; Ważne dla kandydatów do szkót rolniczych, ŻO 1954, nr 68; Traktorzystów-mechaników przygotowywać będa zasadnicze szkoły mechanizacji rolnictwa, GO 1954, nr 179; Technika rolnicze przyjmuja zapisy tylko do 25 czerwca, ŻO 1955, nr 128; Ponad 12 tysięcy młodzieży rozpocznie naukę $w$ pierwszych klasach techników rolniczych, GO 1955, nr 207; W Szkole Mechanizacji Rolnictwa, GO 1956, nr 23; Jednoroczna Szkoła Traktorzystów w Nidzicy przyjmuje kandydatów, GO 1956, nr 243.

${ }^{22} \mathrm{~W}$ związku $\mathrm{z}$ forsowną kolektywizacją rolnictwa powołane zostały w roku szkolnym 1949/1950 szkoły praktyków specjalistów, kształciły na poziomie niższym na potrzeby gospodarki państwowej. W województwie olsztyńskim w roku szkolnym 1949/1950 utworzono 9 takich szkół. $\mathrm{Z}$ braku odpowiedniej liczby kandydatów szkoły te albo nie podjęły pracy, albo działały krótko. Zaczęto więc je likwidować nie tylko w Olsztyńskiem, ale także w całym kraju. 
wym"23. Podobne cele propagandowe i opiniotwórcze miały inne jeszcze artykuły, których intencje zapowiadały już tytuły:

- Rok wielkiego przetomu w szkolnictwie ${ }^{24}$;

- Wielka rola oświaty rolniczej w postepie gospodarczym Warmii i Mazur ${ }^{25}$;

- Młodzież zyskała sympatię chtopów ${ }^{26}$

- Młodzież szkót rolniczych otrzymuje stypendia ${ }^{27}$;

- Nowe szkoty i nowe zawody w stużbie naszego rolnictwa ${ }^{28}$;

- Największe szczęście młodych i dorostych ${ }^{29}$;

- W Karolewie - szkoła wszechstronnego rozwoju ${ }^{30}$.

Inną grupą tematyczną, jaką można wyróżnić w analizowanych publikacjach prasowych, są opisy konkretnych szkół rolniczych, które w latach 19451956 były głównym tematem 35 publikacji. Były to zwykle artykuły korespondentów terenowych ${ }^{31}$, którzy opisywali wrażenia $\mathrm{z}$ pobytu $\mathrm{w}$ danej szkole. W publikacjach tych często przedstawiano historię szkoły, jej obecny wygląd, warunki nauki i warunki socjalno-bytowe uczniów, często zamieszczano „spontaniczne" wypowiedzi uczniów i nauczycieli na temat szkoły. Najczęściej omawiano szkoły w Karolewie, którym poświęcono 22 z 35 publikacji opisujących olsztyńskie szkoły rolnicze. Karolewskie szkoły przedstawiano jako duży i nowoczesny kombinat kształcenia rolniczego ${ }^{32}$. Warto zacytować tu obszerniejsze fragmenty publikacji nie tylko dla wiernego odtworzenia treści, ale również dla ukazania ich wymowy propagandowej. W artykule pod tytułem Największe szczęście mtodych i dorostych pisano:

Zespół Techników Rolniczych im. H. Sawickiej w Karolewie - młodszy brat olsztyńskiej Wyższej Szkoły Rolniczej, rozbrzmiewa znów po wakacyjnej przerwie tysięcznym gwarem młodzieńczych głosów. Sale lekcyjne, dziedziniec szkolny, internaty, duża, lecz w nieskończoność remontowana stołówka - pulsują życiem, tętnią rytmem pracy kombinatu szkolnego. Tu zdobywa-

${ }^{23}$ Podwojona liczba szkół dla praktyków - specjalistów wiejskich, ŻO 1950, nr 315.

${ }^{24} \dot{Z} \mathrm{O} 1950, \mathrm{nr} 228$.

${ }^{25}$ ŻO 1950, nr 129.

${ }^{26} \dot{Z} \mathrm{O} 1950$, nr 128.

${ }^{27}$ ŻO 1951, nr 140.

${ }^{28}$ GO 1954, nr 84.

${ }^{29} \mathrm{GO} 1955, \mathrm{nr} 162$.

${ }^{30} \mathrm{GO} 1954, \mathrm{nr} 107$.

${ }^{31} \mathrm{~W}$ obowiązującym po $1950 \mathrm{r}$. modelu prasy polskiej założono publikowanie jak największej ilości materiałów prasowych przez działaczy społeczno-politycznych, przede wszystkim materiałów korespondentów terenowych oraz listów czytelników. Podkreślano, że inicjatorem ruchu korespondentów terenowych jest partia, a ruch korespondentów jest przejawem udziału mas w rządzeniu państwem i aktywności opinii publicznej.

${ }^{32}$ W 1950 r. w Karolewie powołano jeden z pierwszych w Polsce Zespołów Liceów Rolniczych. Drugim był Zespół Liceów Rolniczych w Cieszynie. Szkoły te miały być wzorcowymi placówkami edukacji rolniczej. Dz.Urz. Ministerstwa Rolnictwa i Reform Rolnych 1950, nr 12, poz. 96. 
ją piękny i odpowiedzialny zawód kadry rolnicze: przyszli technicy i agronomowie, zootechnicy i mechanizatorzy naszego rolnictwa. Im w udziale przypadnie zaszczyt przekazywania naszemu rolnictwu najnowocześniejszych i najlepszych metod uprawy i hodowli oraz zdobyczy nauki. [...] Dnia tego (21 października) od wczesnego ranka do karolewskiego kombinatu przybywają niecodzienni goście, różni wiekiem i powierzchownością. Dobrze pomyślane, co kilkanaście metrów umieszczone strzałki z napisem: 'Do działu korespondencyjnego kształcenia rolniczego' wyjaśniały co ciekawszej młodzieży karolewskiej cel przybycia ich starszych kolegów. Bo trzeba wiedzieć, że niezależnie od stacjonarnej szkoły rolniczej, w której młodzież, głównie wiejska, zdobywa zawód rolniczy i wykształcenie średnie - zespół techników prowadzi inną, bardzo pożyteczną i równie potrzebną, działalność. Tu zdobywają, względnie uzupełniają swe wykształcenie rolnicze pracownicy rolnictwa oraz ci, co z rolnictwem w jaki bądź sposób są związani. Ponad 660 uczniów, pracujących zawodowo w rolnictwie, w radach narodowych, w aparacie partyjnym i społecznym pobierać będzie tu w bieżącym roku naukę [...] Dobra atmosfera dodatnio wpływa, sprzyja dużemu pędowi ludzi starszych do nauki, która jest dziś, w Ludowej Ojczyźnie niewątpliwie największym szczęściem nie tylko dla młodych, ale i dorosłych ${ }^{33}$.

\section{W innej publikacji pisano:}

Kombinatem ochrzciły Karolewo liczne delegacje z Ministerstwa Oświaty, Wojewódzkiej Rady Narodowej, Polskiego Radia, „Trybuny Ludu” i „Sztandaru Młodych”. [...] Określenie to miało swoje podstawy. Karolewo to mały kombinat, w którym uczy się i zdobywa fachową wiedzę rolniczą 1000 młodych dziewcząt i chłopców. Samą uczelnię można porównać do [...] dużego osiedla, którego mieszkańcy wszystko posiadają na miejscu: naukę, rozrywkę i sporty. Czystość wokoło wzorowa. Dyrektor zespołu [...] założył się z nami o „konia z rzędem”, jeśli znajdziemy choćby jeden... papierek. Zakład przegraliśmy. Zamiast papierków - podziwialiśmy pracę dziewcząt i chłopców, którzy mimo że mieli dzień wolny od nauki (był ostatni dzień ferii 21 bm.), raźno po śniadaniu wzięli się do roboty. Dziewczęta porządkowały więc klomby, chłopcy czyścili aleje parku, nawozili piasek, wyrównywali teren szkolnego stadionu. To wszystko musi być zapięte na ostatni guzik. Za kilka dni, od 26 do 28 bm., będzie on widownią szkolnych igrzysk sportowych. Zwiedzaliśmy Karolewo już chyba ze 2 godziny. Zmęczeni rozgościliśmy się w gabinecie dyrektorskim. Ale i tu drzwi nie zamykały się za młodymi interesantami. Najpierw wpadł 16-letni Kurczewski. Zameldował swoje przybycie i oznajmił, że bierze Zetora i rusza w pole. Dyrektor skinął zezwalająco. [...] Potem byłem znowu świadkiem ciekawej narady. Tadeusz Michowski z III klasy mechaniki rolnej przedstawił dyrektorowi projekt, wraz z kosztorysem, oświetlenia stadionu. Położył kartkę zarysowanego papieru na biurku i czekał na „wyrok". Był aprobujący. [...] Tak w lapidarnym skrócie wygląda każdy dzień pracy i nauki w liceum karolewskim. Do południa nauka, potem 2-godzinny odpoczynek, a następnie samodzielne kształcenie praktyczne: w ogrodzie, na traktorze, w oborze, przy uprawie poletek doświadczalnych. Teoria podąża więc w parze z praktyką. To dobrze. Iskierka samodzielności, jaką rozpala szkoła wśród swoich uczniów, wykiełkuje zdrowym owocem doświadczenia. Wychowankowie liceum karolewskiego, którzy zasilą fachowe kadry w służbie socjalistycznego rolnictwa i wyższe uczelnie rolnicze w kraju, siły do pracy czerpią ze szkoły, która ich wychowuje, uczy i usamodzielnia. [...] Wieczór. Uczelniany kombinat karolewski roztętniony w dzień stukrotnym gwarem cichnie, by jutro z tym większym zapałem wziąć się do twórczej i radosnej pracy. Dla kraju i społeczeństwa ${ }^{34}$.

\footnotetext{
${ }^{33}$ Największe szczęście młodych i dorostych, GO 1955, nr 162.

${ }^{34}$ W kombinacie karolewskim. Uczniowie - gospodarzami, ŻO 1954, nr 101.
} 
Prasowy opis karolewskich szkół miał kształtować modelowy wizerunek szkoły rolniczej. W pierwszych publikacjach opisy dziennikarskie skupione były na ciagle polepszających się warunkach pracy, a w latach pięćdziesiątych eksponowaną tematyką były zagadnienia kształcenia i wychowania. Propagowano kształcenie w szkole rolniczej (nie tylko w Karolewie) jako ważny etap na drodze do uspołecznienia i upaństwowienia gospodarki rolnej, wskazywano na związek szkoły z partią, informowano o zobowiązaniach przedzjazdowych ${ }^{35}$ podjętych przez uczniów i nauczycieli w poszczególnych szkołach rolniczych, eksponowano ważność nauczania i wychowania „w duchu marksistowskiej ideologii”. Ważnym tematem dla prasy była działalność kół miczurinowskich, praca i osiagnięcia szkolnych organizacji Związku Młodzieży Polskiej, a w zakresie pracy pozaszkolnej odczyty i spotkania młodzieży szkolnej z mieszkańcami wsi, na których młodzież propagowała korzyści wynikające z kolektywizacji gospodarki rolnej. Marginalnie natomiast potraktowano zagadnienia aktywności sportowej i kulturalnej uczniów szkół rolniczych, mimo że był to zakres edukacji, w której olsztyńska młodzież odnosiła sukcesy.

Eksponowanie bądź marginalizowanie pewnych treści w wypowiedziach prasowych oznacza, że prasa może być źródłem nie tylko faktów, ale postawy mentalnej współczesnych owym faktom wobec zjawisk badanego okresu. Zawartość treściowa prasy nie mogła być wówczas przypadkowa. Ważne bowiem było to, co służyło ,potrzebom rozwoju społecznego, budowania nowego ustroju”36. Prasa stała się ,instrumentem ideologicznego wychowania mas"37. Wykorzystując więc prasę jako źródło, należy uwzględnić specyficzne warunki, w jakich funkcjonowała. W odniesieniu do interesującego nas okresu lat 19451956 podporządkowanie prasy politycznemu dysponentowi (PZPR) oraz ograniczenia cenzury.

\footnotetext{
${ }^{35}$ Zobowiązania te podejmowano z okazji II Zjazdu PZPR.

${ }^{36}$ T. Goban, Komunikowanie masowe. Zarys problematyki socjologicznej, Kraków 1978,

${ }^{37}$ J. Łojek, J. Myśliński, W. Władyka, Dzieje prasy polskiej, Warszawa 1988, s. 166.
} s. 152 . 